\title{
Teehuteatuaonoa aka 'Jenny', the most traveled woman on the Bounty: Chronicling female agency and island movements with Google Earth
}

\author{
Donald Patrick Albert \\ Department of Environmental and Geosciences, Sam Houston State University, USA \\ geo_dpa@shsu.edu
}

\begin{abstract}
Teehuteatuaonoa (or 'Jenny' by her English nickname) was one of 12 Polynesian women reaching Pitcairn Island with the HMS Bounty mutineers in 1790. She was the most traveled of these women and the first to return to Tahiti after 29 years away. Her journey is chronicled with Google Earth using a screenshot and caption for each waypoint. The journey included 15 links totaling 24,090 km or $60 \%$ of the Earth's circumference. Her longest link was 7,400 km aboard the Sultan, an American ship from Boston, which brought her from Coquimbo, Chile, to The Marquesas. Jenny's life provides an excellent example of female agency during a period controlled and reported on by men. Her life epitomized Nicholas Thomas' understanding that islander-empire contact during the $18^{\text {th }}$ and $19^{\text {th }}$ Centuries involved both survival and suffering, invention and exploitation.
\end{abstract}

Keywords: female agency, Google Earth, islands, mutiny on the Bounty, Teehuteatuaonoa, Pitcairn Island

https://doi.org/10.24043/isj.153 • Received April 2020, accepted January 2021

(C) Island Studies Journal, 2021

\section{Introduction}

On 28 April 1798 the most infamous of mutinies occurred in the South Seas as Acting Lieutenant Fletcher Christian deposed the commanding officer Lieutenant William Bligh of the HMS (British) Bounty (Kirk, 2008). With its pirates, gorgeous women, and exotic islands, the mutiny on the Bounty continues to captivate the public, amateur enthusiasts and scholars across a wide range of academic disciplines. A continuing stream of books, magazines and academic journals have covered the mutiny and its aftermath. A series of historicallyindulgent, inaccurate, but romantic big screen films starring Wilton Power and George Cross (1916), Errol Flynn and Mayne Lynton (1933), Clark Gable and Charles Laughton (1935), Marlon Brando and Trevor Howard (1962), and Mel Gibson and Anthony Hopkins (1984) have dramatized this legendary event. Marlon Brando became mesmerized with the people, places, and environment of Tahiti. This type of infatuation is what Connell (2003) termed "island dreaming." Even before Brando, this phenomenon infected other famous expatriates such as Robert Louis Stevenson, Paul Gauguin, and Bengt Danielsson among others. Just as 
Fletcher Christian married his love interest, Mauatua, and escaped to an island hideaway, so did Brando. He married Tarita Teriipia, his supporting actress from Mutiny on the Bounty (1962), and purchased a French Polynesian atoll (Tetiaroa). Brando's personal life manifested parallels to that of Fletcher Christian, including a fondness for challenging the status quo.

These films, however, and much of the historic archives and ensuing literature, gloss over the role the Bounty's women had in shaping the social and cultural milieu from its inception in 1790 to 1850 when Teraura (Susannah), the last surviving woman, died (Nicolson \& Davies, 1997). It is reasonable then that Mauatua, Teraura, and the other women would be considered prime candidates for biographical analysis. Glynn Christian's (2011) historical fiction, Mrs. Christian: 'Bounty' Mutineer, offers one probable elaboration of female agency post-mutiny. From a geographer's perspective, Teehuteatuaonoa (or Jenny by her English name) is an interesting choice because she traveled farther than her female compatriots involved with the mutineers. Jenny's journey encompassed a full circle that started and ended in Tahiti. Her path is captured in Google Earth using a 'mapping a story' strategy espoused by Pat Oden (2004) to conceptualize space and places within a narrative.

This study examines Teehuteatuaonoa's waypoints or whereabouts from contemporaneous sources. Her story was recorded and interpreted by men and mostly for men. Naval officers, on encountering women, would often comment on their physical attributes using such descriptors as handsome, fine figures, beautiful teeth and fine hair, and surmise disposition, even after short visits, as simple and innocent (Raine, 1821). This language is reminiscent of the French Romantic notion of 'le bon sauvage' - the innate goodness of people uncorrupted by the influence of civilization.

That an indigene is equal to a simpleton without sophisticated reasoning capabilities is argued in early chronicles from Pitcairn Island. During Lieutenant James Lowry's visit to Pitcairn on the HMS Sparrowhawk in 1839, he remarked that the once-fair maiden of the South Seas, Mary Ann Christian, was "as cross and crabbed as any old maid need be; she rails against the early marriages most heartily" (Nicolson \& Davies, 1997, p. 168). In the three years (1836-1839) preceding Lowry's visit there occurred a string of young brides $(14,14$, 15, 12, and 14). While Lowery interpreted her objections as carping, her warnings were ironic, given the sex abuse scandal that rocked the island in early 2000s (Ball, 2004). Maledominated narratives often objectified women and ignored female agency in negotiating and shaping their social milieu, leaving women's voices attenuated, thwarted, or twisted. The reality was that women facilitated networking between familial, social, and political connections for those mutineers remaining in Tahiti, during their failed settlement on Tubuai, and on Pitcairn Island (Reynolds, 2016). During the first decade on Pitcairn Island, the women were active and sometimes violent participants in a real-life game of survival. One might assume the lives of the women and children eased into a more peaceful existence after 1800 when all the mutineers except John Adams had died by murder, accident or natural cause.

While visitors during early contacts with the islanders often ignored or misinterpreted the words of women, their voices live on through the study of dye and designs on tapa cloth. These objects of history, gifted to visitors and friends, are in private and public collections around the world. The tapa cloth samples highlight the traditions, training and education, and innovation these women promulgated on this remote island settlement (Reynolds, 2016). Jenny's mention of cultivating and processing the 'cloth plant' to produce traditional Polynesian garments such as the maro, paren, and te tibuta corroborate the significance of this 
activity during the early Pitcairn years (Teehuteatuonoa, 1819, 1829). Pauline Reynolds (2011a) recognized all 12 of the original women to settle Pitcairn Island as agents of change in her essay titled Our Polynesian Foremothers.

The $18^{\text {th }}$ Century contacts between Polynesians and Europeans, beginning with Samuel Wallis' encounter on the HMS Dolphin (British) and continuing through the visits of Bougainville (French), Boenechea (Spanish), Cook and Bligh (British), and others demonstrate vagaries of agency and structure. The Tahitians' willingness to initiate taio or friendship bonds, exchange gifts, accommodate trading requests, and offer 'amorous' young girls was a strategic plan to forge alliances to transform personal status and ultimately the political landscape (Salmond, 2011). The Tahitian chiefs were interested in securing muskets, powder, and shot, and even joining forces with the Europeans to defeat rivals from other districts. While Cook received an exuberant reception on approaching Tahiti for his first and second expeditions (1769, 1773), approaching Vahitepiha Bay during Cook's third and last voyage (1777) brought almost no notice- their initial welcome consisted of just two canoes and disappointedly no women. However, after learning that the HMS Endeavor brought with it a stash of red feathers used in Oro worship, the Tahitians' attitude toward the British took an about-face. The reason for the cool reception initially is that between Cook's second and third visit, two Spanish ships under Boenechea's command (1774) arrived in Tahiti. Maximo Rodriguez, an enterprising marine attached to the Boenechea expedition, forged alliances with the political elite including $\mathrm{Tu}$, the paramount chief, and Vehiatua III, a high chief from southern Tahiti. Between drinking ava and having affairs with local women, Maximo convinced $\mathrm{Tu}$ and Vehiatua III that the Spanish and British were enemies. With Cook's departure from Tahiti fast approaching, Moana, high chief of Matavia Bay, sought to forge an alliance with the British. He invited British officers to a lavish feast and offered them "women as bedfellows" (Salmond, 2011, p. 82). These examples illustrate how the 'le bon savange' concept is insufficient for describing encounters between these islanders and Europeans (Thomas, 2010). For the remainder of this article, the focus turns from group (national, district, clan) to individual agency using the case of Jenny, the most traveled woman of the Bounty.

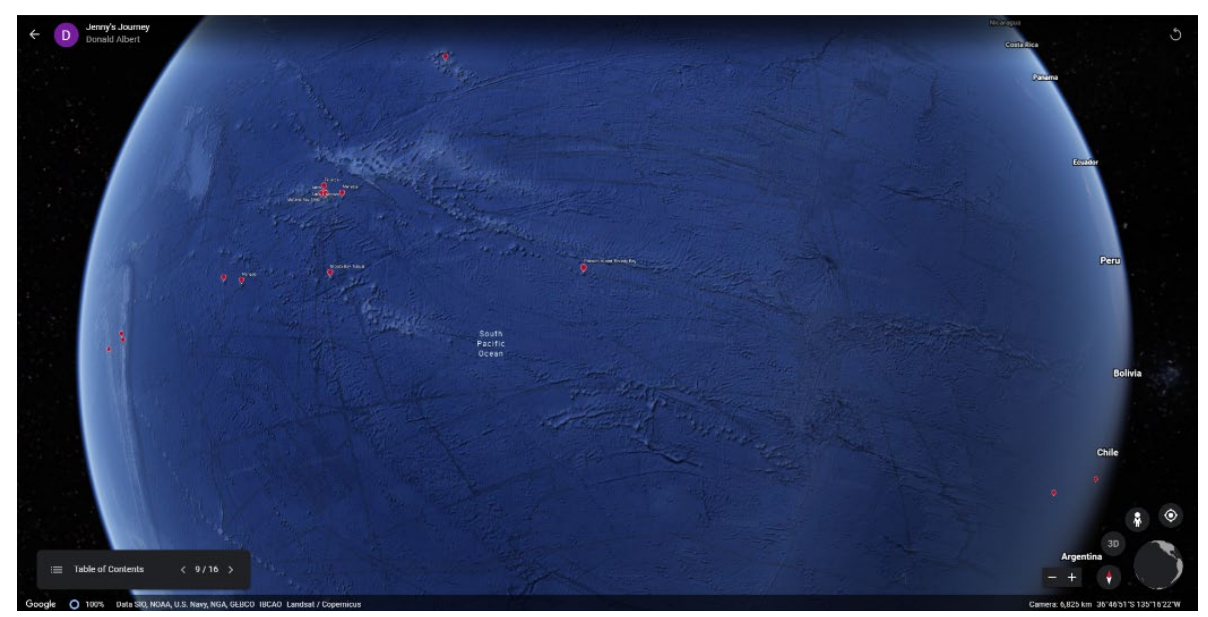

Figure 1. Google Earth (n.d.), The South Seas (16 February 2020).

In this study, Jenny's journey is captured and analyzed using Google Earth (2020). Her initiative, determination, and presence ensured that her voice would be heard then and, for that 
matter, over 200 years later. These characteristics enabled her to return to Tahiti using her own initiative. Pauline Reynolds (2001b, p. 1) astutely christened the Bounty women as the "most travelled [...] of their day," and of the 12, Jenny covered the greatest distance (Figure 1).

This investigation highlights a social and historical geography application of Google Earth. It recognizes that outside contacts with British, Spanish, French and American explorers and scientists, whalers and sealers, missionaries, and traders venturing into the South Seas during the $18^{\text {th }}$ and $19^{\text {th }}$ Centuries made possible the movement of individuals across the Pacific Ocean. Jenny's journey provides an opportunity to document female agency in shaping herstory in a male-subjugated era.

This project has relevance beyond enthusiasts of the Bounty saga. Those in geography education might find this study contributes to pedagogic applications of Google Earth. For example, others have employed Google Earth for assessing place location knowledge (Zhu, Pam, \& Gao, 2016), teaching maps skills and concepts (Hsu, Tsai, \& Chen, 2018), illustrating national or state geography standards (Patterson, 2007), teaching data and spatial analysis (Kulo \& Bodzin, 2011; Schultz, Kerski, \& Patterson, 2008), examining land use change (Bodzin \& Cirucci, 2009), and creating virtual field trips (Krakowka, 2012).

\section{Jenny's life story}

Teehuteatuaonoa, known by her English name 'Jenny', was one of the original settlers of Pitcairn Island. Like most of the 12 women brought to Pitcairn Island, she came from Tahiti. She joined the Bounty after its arrival on Tahiti on 6 June 1789 to 'load' women, pigs, goats, chickens, some plants, and even dogs and cats for their planned settlement on Tubuai, dubbed Fort George, 350 miles to the south (Nicolson \& Davies, 1997; Wahlroos, 1989). Jenny had initially been paired with Alexander Smith (John Adams), but between Tubuai and Pitcairn Island she became coupled with Isaac Martin for reasons unknown (perhaps love). On arriving at Pitcairn Island on 15 January 1790 (Murray, 1992), she was one of 12 women, an infant female (Sully or Sarah), and six men from Polynesia brought by the Bounty. The British contingent included Fletcher Christian and eight other mutineers for a total of 28 people (Wahlroos, 1989). The sex ratio, consisting of 15 men and 12 women, did not allow for a one-to-one coupling. The numerical imbalance between males and females, the decision to divide land just among the mutineers, promiscuity, and the mistreatment of the Polynesian men fueled animosities that instigated murders between both camps (Silverman, 1967). After Jenny's husband was killed on 20 September 1793, known as Massacre Day, she remained on Pitcairn Island until 17 October 1817 when she boarded the Sultan, an American whaler from Boston headed for Chile on the Spanish Main (Ford, 1996). She reached Tahiti about ten months later, where perchance she was twice interviewed and had an encounter with a Russian naval officer in March 1824 (Kotzebue, 1830).

Jenny's accounts are considered less biased than those of the last surviving mutineer and patriarch, John Adams (alias Alexander Smith), whose versions of events obfuscated his role in the mutiny and actions on Pitcairn Island (Scott, 1982). That she had no children, and therefore no grandchildren, made her decision to leave less complicated. While Jenny is not among the six original matriarchs (i.e., Mauatua, Teio, Teraura, Tevarua, Toofati, and Vahineatua) of Pitcairn Island (Langdon, 2000), her value to the Bounty saga is enhanced because of her eyewitness accounts of life after the mutiny. These were published in period 
newspapers and a book and have been used to confirm, dismiss, and even triangulate understandings of life after the mutiny, both aboard the Bounty and on Pitcairn Island.

While Jenny is the only woman to return for a substantial period, and that after 29 years, four others returned to Tahiti in the disastrous 1831 relocation when an epidemic eliminated about one-fifth or 16 of the Pitcairners (Kirk, 2008). Within months, the two surviving women, Mauatua (Mainmast) and Teraura (Susannah), returned to Pitcairn Island. Toofaiti and Vahineatua died in the epidemic and became unintended casualties of this disastrous relocation (Nicolson \& Davies, 1997). In a bit of confusion, Jenny recounts a pregnant Vahineatua dying after being ignominiously "pierced" by a goat (Teehuteatuaonoa, 1819). This occurred before Jenny left Pitcairn Island in 1817; however, others recorded Vahineatua's death as occurring during the Tahitian interlude on 29 April 1831 (Nicolson \& Davies, 1997; Lareau, 1999). Jenny's first interview does illustrate that this account should not necessarily be considered fully accurate in every respect.

\section{Physical and intellectual characteristics}

The French explorer Louis de Bougainville, who visited in 1768, considered Tahiti a terrestrial paradise. He imagined he had been transported to the Garden of Eden, replete with fruit trees and a turf-covered landscape (Salmond, 2010). Bougainville named this island New Cythera after the birthplace of Aphrodite, the Greek goddess of love, because the women were considered "sexually receptive and alluring" (Tamaira, 2010, p. 1).

Teehuteatuaonoa or Jenny was born on Tahiti (Laureu, 1999). She joined the Bounty on 6 June 1789 during Fletcher Christian's short visit to Tahiti to kidnap or otherwise secure women and supplies for their planned settlement on Tubuai (Teehuteatuaonoa, 1829). One anonymous account described her as attractive and "apparently a good looking woman in her time, but now begins to bear the marks of age" (Teehuteatuaonoa, 1819). The observer noted that her hands were "quite hard with work," a legacy of cultivating the fields while living on Pitcairn Island (Teehuteatuaonoa, 1819).

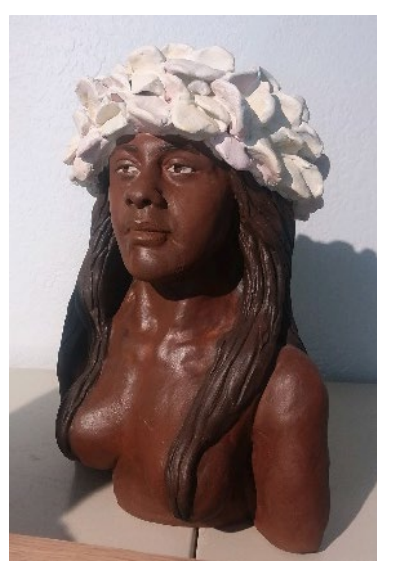

Figure 2. Rendition of Jenny by Robert Brown, as photographed at the Pitcairn Islands Study Center, Pacific Union College, Angwin, California. Source: Author's photograph.

What did Jenny look like? There is a collection of clay busts of Bounty and Pitcairn characters (Bligh, Christian, Heywood, and others) on display at the Pitcairn Islands Study Center located on the campus of Pacific Union College in Angwin, California. Robert Brown 
sculpted some of these from descriptions and portraits; however, most were based on impressions. The bust of Jenny is depicted with dark-skin and topless, the stereotypical mythical goddess so enshrined within western man's image of Polynesian women, past and present (Figure 2).

I could critique the bust based on its color, a deep, dark brown for skin tone. One could also investigate whether her eyes and hair were dark brown, or whether she was normally topless and wore flowers around her head. These matters would be serious endeavors involving biological (genetics) and cultural investigations. George Robertson, master of the HMS Dolphin, noted there were a "good number" of light-skinned Tahitians during his 1767 visit (Langdon, 2000). Langdon calculated that between 3,500 and 10,000 Tahitians would have been "predominantly white," depending on what initial population estimate was used. Robertson observed that light-skinned individuals were of the chiefly class and dark-skinned individuals of the servant class. Bougainville, a French explorer, found the light-skinned inhabitants tall, well-proportioned and with European features. The European genes were later attributed to the crew of a missing Spanish ship that entered and disappeared in the Pacific in 1526. There were about 53 sailors including Galicians, Basques, other Spaniards, Germans, Flemings, Italians, and others that contributed to the gene pool 240 years before the arrival of the Dolphin (Langdon, 2000). The 'atua' in Jenny's given name translates as privileged, and according to Reynolds (2011b, pp. 1-2):

Their names can be broken down into meaningful morphemes indicating their privileged upbringing through the use of atua (god or godliness), through references to goddesses, to chiefly families of the day, sacred marae (area for ceremonial and religious purposes), the heavens, the spirit, the sacred colour red.

Jenny was one of four of the women who had 'atua' embedded in their Tahitian names: Mauatua, Vahineatua, Teehuteatuaonoa, and Teatuahitia. Two other names also suggest privileged persons: Toofaiti translates as 'petty sub-chief and Tevarua translates as 'the soul' (Langdon, 2000). According to Reynolds (2011b), only women from higher classes could associate with the early European visitors, unless authorized by district chiefs. She noted that ten of the 12 Polynesian women brought to Pitcairn Island in 1790 had morphemes or elements in their names that indicated nobility (Reynolds, 2011a).

Wahlroos (1989) surmised that Jenny was an intelligent person and a leader among the women of Pitcairn. There are numerous accounts indicating she was a woman of action. For example, her switching dalliance from Smith to Martin and insisting on passage on the Sultan in 1817 were mentioned above. However, there were still other occasions when her sense of agency was recorded for posterity. Mutineer Edward 'Ned' Young started a journal of island happenings around December 1793. Although Young's journal was lost to later generations, Captain Beechey's Narrative of a Voyage to the Pacific quotes from it during an 1825 visit to Pitcairn Island. These passages exemplify Jenny's determination, singlemindedness, and penchant to throw caution to the wind. On 12 March 1794, Young wrote "Going over to borrow a rake, to rake the dust off my ground, I saw Jenny having a skull in her hand: I asked her whose it was? And was told it was Jack Williams's. I desired it might be buried: the women who were with Jenny gave me for answer, it should not" (Beechey, 1831, p. 89). One month later, the men were indulging the women's request to build a boat for their 
planned escape. Summarizing Young's entry, Beechey wrote, "but wanting planks and nails, Jenny, who now resides at Otaheite, in her zeal tore up boards of her house" (Beechey, 1831, p. 89). Mr. Downs, $2^{\text {nd }}$ officer on the Sultan, described her entreaties to leave with the Sultan as "very earnest" (Topliff, 1821). According to Fitzsimons (2018), Jenny actively plotted with mutineer Young and two of the women (Tevarua and Teraura) to kill the last two Polynesian men: Tetahetie (axed) and Nehow (shot). Kotzebue (1830, p. 250) recorded that she boasted of the vengeance during his encounter with her on Tahiti in 1824. It is clear that Jenny was not someone to be trifled with. These accounts were all recorded, transcribed, or interpreted through the 'eyes' of men, and some seem simplified explanations and even pejorative. Jenny was no wallflower, but full of vim and vigor in pursuing her desires or standing her ground.

Jenny had a tattoo inscribed 'A S 1789' on her left arm, an indication that initially she was linked to Alexander Smith. Comments on her English spanned the spectrum from "tolerably good [...] but with a foreign accent" (Kotzebue, 1830, p. 249) to unable to speak either English or Tahitian, "but a jumble of both" (Teehuteatuaonoa, 1819). Kotzebue said she held John Adams in high regard, even though it had been seven years since leaving Pitcairn. Jenny, Kotzebue wrote, expressed "vehement indignation" toward the Polynesian men that murdered the English and 'boasted' of her vengeance (Kotzebue, 1830). Wahlroos (1989) emphasized that Jenny became homesick for life on Pitcairn Island and would have likely returned if she were still alive when her friends from Pitcairn arrived at Tahiti in 1831. The Tahitian way-of-life of her youth was fast changing with the increasing exposure to the arrival of sailors and scientists, whalers and sealers, traders, and missionaries from Britain, France, and America. Lareau (1999) said she contacted the Pitcairners during the disastrous immigration to Tahiti in 1831 and died soon afterwards; however, this statement is unsubstantiated.

\section{Two interviews and an encounter}

Henry E. Maude, a colonial administrator, located two newspaper items containing interviews with Jenny after her return to Tahiti. The existence of these sources had been forgotten prior to Maude's rediscovery (1958). The first account appeared in the Sydney Gazette and New South Wales Advertiser on 17 July 1819 and was sponsored by the British and Foreign Bible Society, a nondenominational Christian organization formed in London in 1804. While this article is often attributed to Jenny, this account was passed on to the editor by an unnamed source-a Sydney "gentleman" recently returning from the Society Islands who had an encounter with Jenny. The second interview appeared in the Bengal Hurkaru on 2 October 1826 and contained an account dictated by Jenny to the Reverend Henry Nott while in the presence of Captain Peter Dillon. Nott and Dillon spoke fluent Tahitian (Maude, 1958). Henry Nott, a missionary of the London Missionary Society, had devoted his life to the Tahitian mission. He is remembered for translating the Bible into Tahitian (Reason, 1938). Peter Dillon was a trader, explorer, and writer famous for solving the mystery of the lost La Pérouse expedition (Dillon, 1829). Both men were versed in the culture and language of Tahiti and in a position to record Jenny's account with nuance and precision. The information in the two newspaper articles allowed Maude to recreate the trajectory of the Bounty after leaving Tahiti for the last time and until its arrival on Pitcairn Island in January 1790.

In a third account, Otto Von Kotzebue, a Russian naval officer and Pacific explorer, recounts a brief encounter with Jenny in Tahiti during March of 1824 (Kotzebue, 1830). Kotzebue found that Jenny had become disillusioned about returning to Tahiti and yearned 
for Pitcairn Island; had she been alive when the Pitcairners immigrated to Tahiti, it is likely she would have joined them in their return to Pitcairn Island in 1831.

While these interviews are consistent and valuable, her accounts required translation and interpretation before being disseminated. For example, in the first interview, she refers repeatedly to Adam Smith, rather than Alex or Alexander Smith, his alias, or John Adams, his actual name (Teehuteatuaonoa, 1819). Here she is combining, respectively, his actual and alias last names. While in the second interview, she used his alias, Alexander Smith, with John Adams included in parentheses, presumably added by an editor (Teehuteatuaonoa, 1829). The passage of time may have dampened her memory or perhaps distortion introduced via male editors have made her accounts less than 100\% accurate. Nonetheless, the information gleaned from Jenny has stood the test of time and proven useful to those interested in tracking the path of the Bounty post-mutiny.

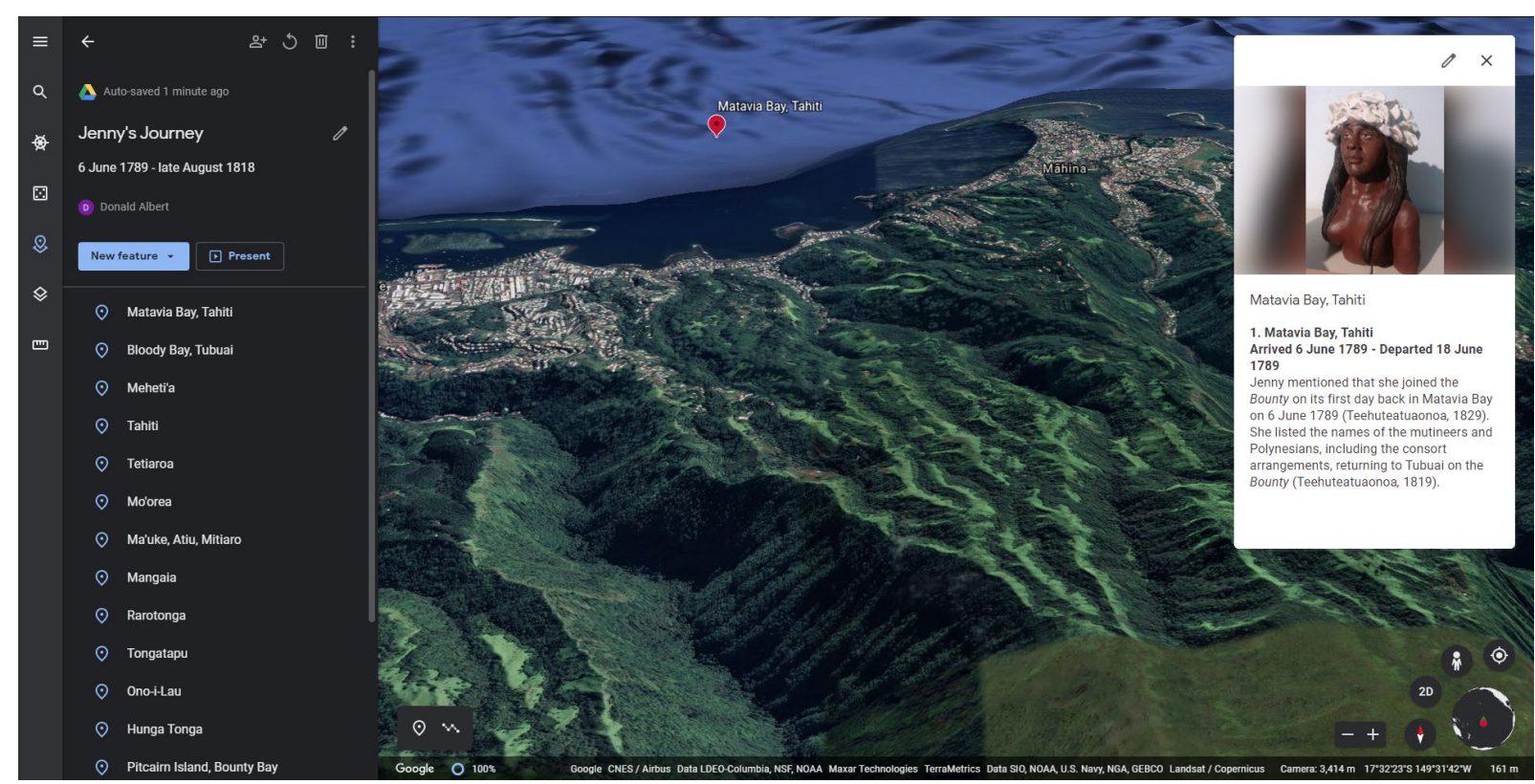

Figure 3. Google Earth's interface showing display functionality: map scale (- or + ), direction, perspective (2D or 3D), Street View (bottom right), photo/text box (top right), distance and other tools (far left column), and table of contents (near left column). Source: Google Earth (n.d.), screenshot from 24 February 2021.

\section{Jenny's journey from and to Tahiti: 1789-1818}

Jenny's circuitous route took her across the South Pacific, a journey that began in 1789 and ended in 1818. Her journey started and ended in Tahiti with 15 links connecting waypoints along her route. The waypoints were either onshore (that is, actual landings) or offshore positions. All waypoints were placed in a Google Earth project (Figure 3). The images retrieved for each waypoint are included in Table 1. The screenshots appearing in Table 1 are oriented with north at the top of the image, some are in $2 \mathrm{D}$ and others $3 \mathrm{D}$, depending on the option selected. Each image includes a caption describing the events or other salient facts occurring at its waypoint. Google Earth allows one to 'fly' from one waypoint to another using the 'present' command in projects. The software offers editing features to change the symbol size and color and font characteristics. Within Google Earth, 'settings' offer additional 
functionality; for example, adding titles, subtitles, and text or accessing and inserting photographs (Figure 3). Readers can access Jenny's Journey by inserting this link in Google Chrome: https://earth.google.com/earth/d/1cznPeoSHBZ7V2gjcvsL8DOQzdvmESu8k?usp=sharing.

Table 1. Google Earth screenshots and captions documenting Jenny's journey, 1789-1818. Source: Google Earth (n.d.), screenshots from 16 February 2020.

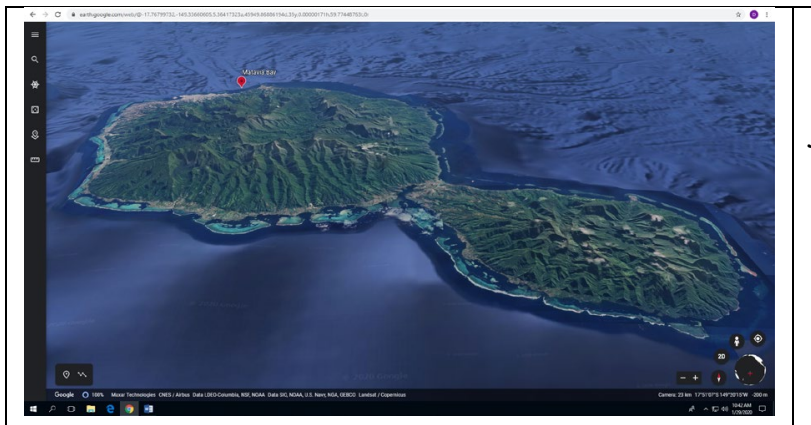

1. Matavia Bay, Tahiti: Arrived 6 June 1789 - Departed 18 June 1789

Jenny mentioned that she joined the Bounty on its first day back in Matavia Bay on 6 June 1789 (Teehuteatuaonoa, 1829). She listed the names of the mutineers and Polynesians, including the consort arrangements, returning to Tubuai on the Bounty (Teehuteatuaonoa, 1819).

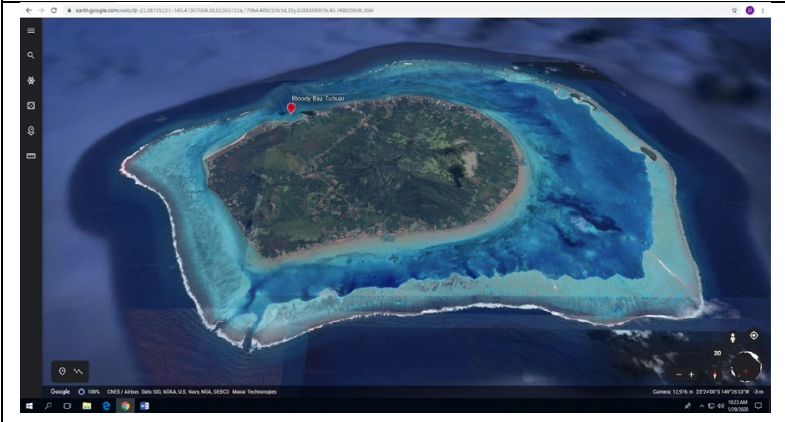

\section{Bloody Bay, Tubuai: Arrived 23 June 1789 - Departed 17 September 1789}

Jenny mentioned the construction of two structures and a fort (Fort George), and described a failed scheme to capture the Bounty (Teehuteatuaonoa, 1829).

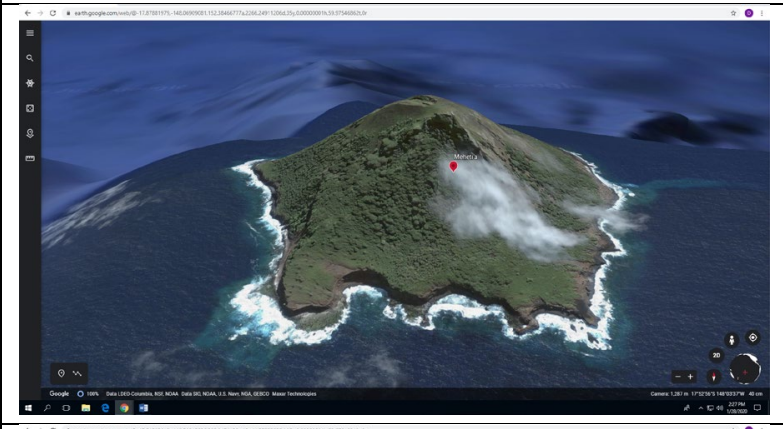

3. Offshore from Meheti: 20 September 1789

Just east southeast of Matavia Bay, stores, arms and ammunition from the Bounty were divided into shares among those electing to remain in Tahiti (Maude, 1958).

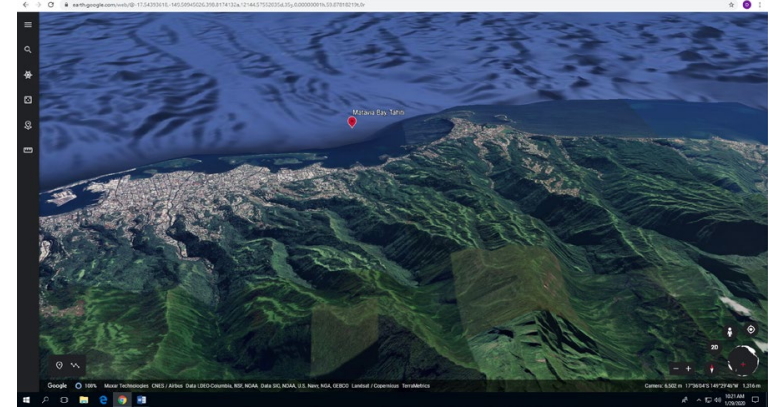

4. Matavia Bay, Tahiti (Society Islands): Arrived 22 September 1789 - Departed 23 September 1789

16 individuals were shuttled to shore with their possessions (Wahlroos, 1989); Fletcher Christian requested Peter Heywood to transmit "certain matters" to his family should he return to Britain (Maude, 1958). After sunset, with the Bounty cable cut, she drifted farther offshore; an intrepid woman jumped overboard and swam ashore (Teehuteatuaonoa, 1829). 


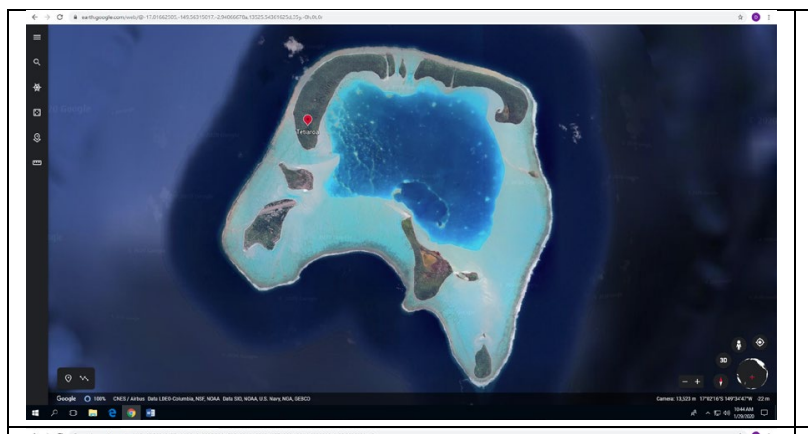

5. Tetiatora (offshore), 26 miles north of Matavia Bay: 23 September 1789

Consort assignments were confirmed, with one woman for each mutineer and three women to share between the six Polynesian men (Maude, 1958; Teehuteatuaonoa, 1829).

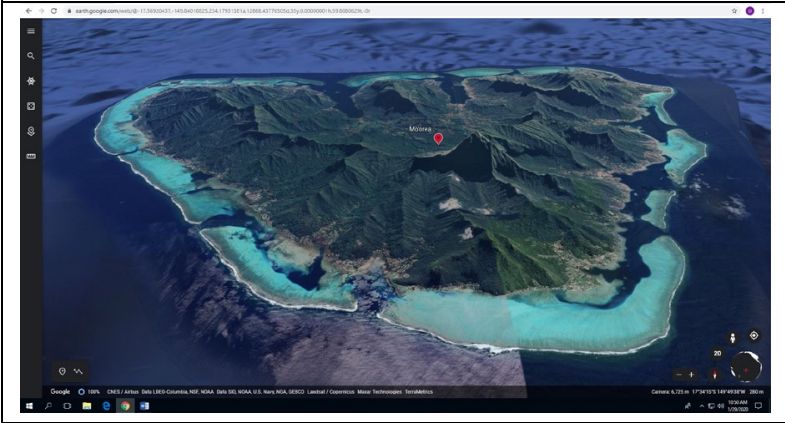

6. Moorea (offshore), just over 30 miles southwest Tetiatora and 9 miles west of Tahiti: 23 September 1789

Six "rather ancient" women allowed to depart on an approaching canoe, after which the Bounty sailed westward (Maude, 1958; Teehuteatuaonoa, 1829).

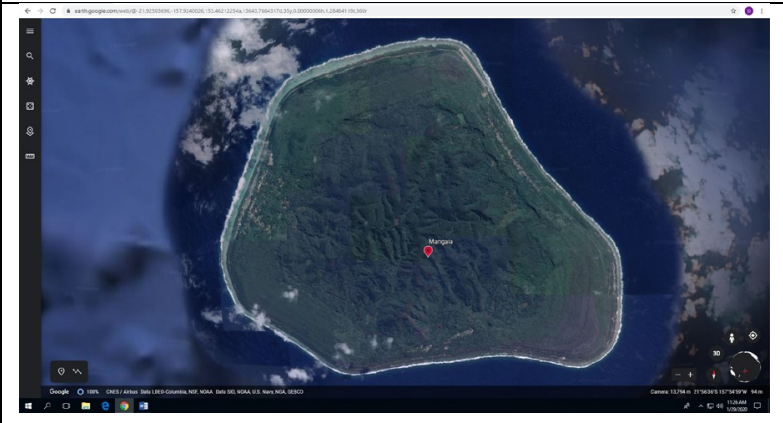

7. 'Purutea' - (offshore) perhaps Mauke (east), Atiu (west) or Mitiaro (north): 135 to 175 miles northeast of Rarotonga While Purutea "could have been Rarotonga," Maude (1958) initially thought it could be Mauke, Atiu, or Mitaro, but Edwin Gold's acquisition of The English Physician Enlarged (1784) in 1946 from Mangaia convinced Maude otherwise. Local tradition thought the medical reference derived from 'papaa, ship like a garden', a fitting description of the Bounty (Denning, 1992; Maude, 1968). Here (Purutea?), an unfortunate incident occurred revealing that at least one of the mutineers, never named, was indeed a despicable human being. A native was standing on the gunwale showing off to his companions a pearlbuttoned jacket just received from Fletcher Christian. In an act of sheer meanness, a mutineer shot dead this native, causing him to fall overboard (Maude, 1958). Jenny commented that though Christian was dismayed, he "could do nothing more, having lost all authority" (Teehuteatuaonoa, 1829). 

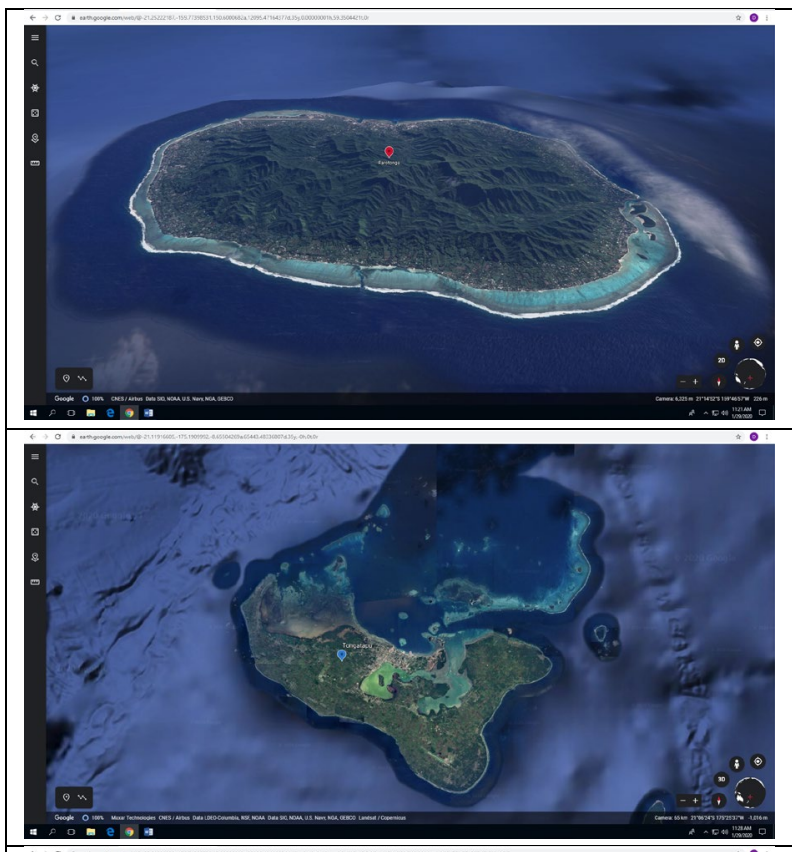

8. Rarotonga (offshore), Southern Cook Islands

Orange cultivation on this island traces its roots (seeds) from a large box stolen by Maia, a Rarotongan, from the Bounty (Maude, 1858).

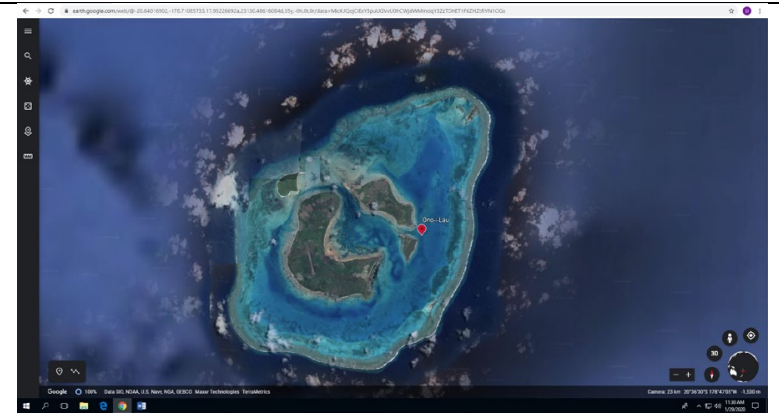

10. Vivini (either Ono-i-Lau or Vatoa of Southern Lau Group, Fiji)

After Tongatabu, Jenny mentioned encountering a "small low island" that interested Christian (Teehuteatuaonoa 1829). Maude surmises Vatoa, given its similar latitude to Rarotonga. A boat went sent ashore and gathered some birds, eggs, and coconuts, however, the island had numerous inhabitants and was therefore not a suitable hideaway (Maude, 1958).
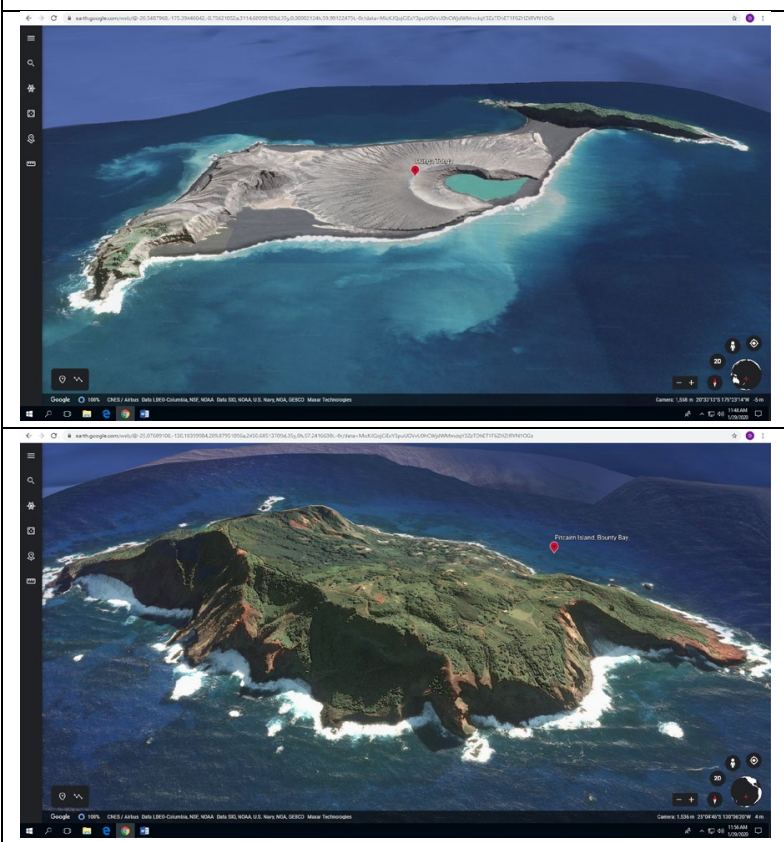

12. Pitcairn Island, Bounty Bay:

Arrived 15 January 1790 (offshore), 20

January 1790 (onshore) - Departed 17

October 1817 on the Boston whaler Sultan

The Sultan on route from the Marquesas to Massa Fuero (Alejandro Selkirk Island) and then on to Coquimbo (Chile) (Ford, 1996; Topliff, 1821; Wahlroos, 1989). 


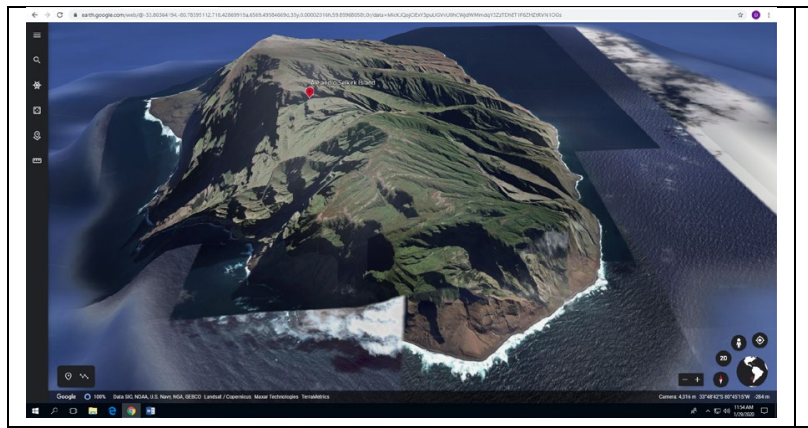

13. Sultan passing Massa Fuero (Alejandro Selkirk Island)

This island was known for its seals until hunting exterminated the population in the mid-19 $9^{\text {th }}$ Century.

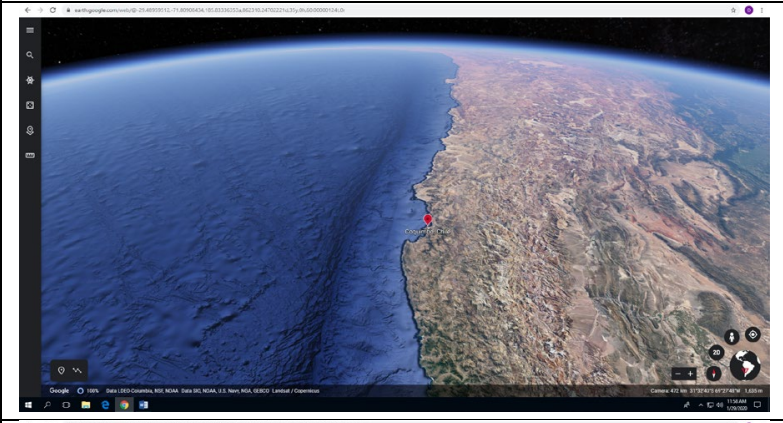

14. Coquimbo, Chile: Arrived 19 November 1817 - Departed: 18 April 1818

Nothing is known about the five months Jenny spent in Chile, except that she boarded the Sultan to The Marquesas.

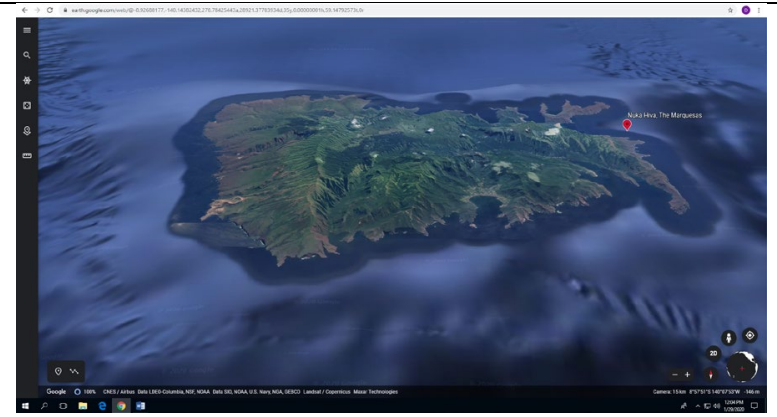

15. The Marquesas, (Nooaheevah, Nugahiva): Arrived 21 May 1818 on Sultan - Departed late August 1818

Jenny stayed three months at Nugahiva, The Marquesas, before joining the three-mast British colonial ship the King George to Tahiti (Teehuteatuaonoa, 1819). Doing the math, Jenny's return to Tahiti took between nine and ten months, much of it waiting in Chile and the Marquesas.

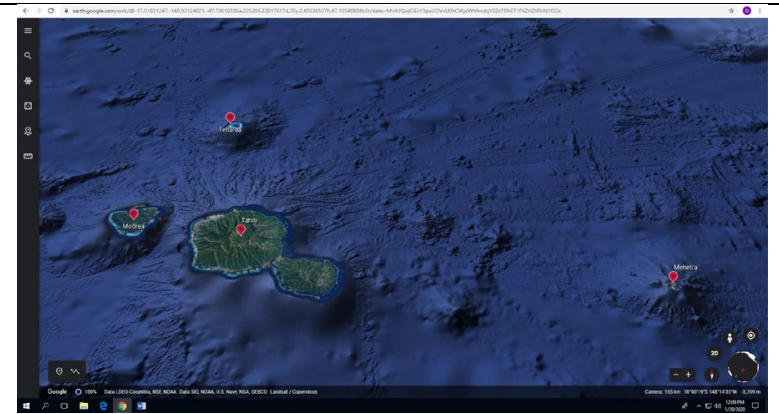

\section{Return to Tahiti: Arrived late} August 1818

First interview published in Sydney Gazette (Teehuteatuaonoa, 17 March 1819). Second interview published in Bengal Hurkura (Teehuteatuaonoa, 2 October 1826, reprinted in United Service Journal and Naval and Military Magazine, 1929). Encounter March 1824 (Kotzebue, 1830).

Death: Prior to 23 March 1831 according to Wahlroos (1989) or just after, per tradition (Lareau, 1999).

Table 2 summarizes the waypoints from Tahiti (1789) to Tahiti (1818). The journey itself encompassed 29 years, with most of that time being spent on Pitcairn Island. According to Herb Ford, the Sultan was the fourth ship to visit Pitcairn after its "rediscovery" by Mayhew Folger on the Topaz of Boston (1808); the others were the HMS Briton and HMS Tagus (1814), with Captains Staines and Pipon, respectively (Ford, 1996). There were 16 waypoints and 15 links or from-to connections, beginning with her initial trip from Matavia Bay (Tahiti) to Bloody Bay (Tubuai) and ending with her final trip from The Marquesas to 
Tahiti. Distances between links were calculated within Google Earth using the great circle, or the shortest distance between two points on a sphere (Table 2). The assumption is that the shortest routes were taken for each link, but this is just an approximation, as it ignores ocean currents, wind patterns, weather, and seasons, which might have had a bearing on the actual route (Albert, 2018). However, for our purposes, the great circle route is an acceptable measure of the distances covered. Jenny's journey spanned much of the east-west expanse of the South Seas, an amazing journey for an individual from her time and place.

Table 2. Great circle distance between waypoints.

\begin{tabular}{|c|c|c|}
\hline From & To & $\begin{array}{c}\text { Distance (km) } \\
\text { rounded to nearest } 5 \mathrm{~km}\end{array}$ \\
\hline Matavia Bay, Tahiti & Bloody Bay, Tubuai & 645 \\
\hline Bloody Bay & Meheti & 620 \\
\hline Meheti & Matavia Bay & 160 \\
\hline Matavia Bay & Tetiatora & 55 \\
\hline Tetiatora & Moorea & 960 \\
\hline Moorea & Mangaia & 205 \\
\hline Mangaia & Rarotonga & 3,600 \\
\hline Rarotonga & Tongatabu & 375 \\
\hline Tongatabu & Ono-i-Lau & 4,455 \\
\hline Ono-i-Lau & Hunga Ha'apai \& Hunga & 4,830 \\
\hline Hunga Ha'apai \& Hunga & Tonga & 1,000 \\
\hline Tonga & Bounty Bay, Pitcairn & \\
\hline Pitcairn Island & Island & 7,400 \\
\hline Massa Fuero (Alejandro & Selkirk Island) & 1,385 \\
\hline Selkirk Island) & Coquimbo, Chile & \\
\hline Coquimbo & The Marquesas & \\
\hline The Marquesas & Tahiti & \\
\hline & & \\
\hline
\end{tabular}

Table 3 contains a list of waypoints, places, cumulative distances, and year of travel for Jenny. Figure 4 provides a network graph of these waypoints and some of the place names added for reference. This figure emanates from a PowerPoint slide and has been designed with the option to display each link sequentially. 
Table 3. Waypoints, places, cumulative distance and year.

\begin{tabular}{|c|c|c|c|}
\hline Waypoints & Places & $\begin{array}{c}\text { Cumulative } \\
\text { Distance } \\
(\mathbf{k m})\end{array}$ & Year \\
\hline 1 & $\begin{array}{c}\text { Matavia Bay, } \\
\text { Tahiti }\end{array}$ & 0 & 1789 \\
\hline 2 & Bloody Bay & 645 & 1789 \\
\hline 3 & Meheti & 1,265 & 1789 \\
\hline 4 & Matavia Bay & 1,425 & 1789 \\
\hline 5 & Tetiatora & 1,480 & 1789 \\
\hline 6 & Moorea & 1,535 & 1789 \\
\hline 7 & Mangaia & 2,495 & 1789 \\
\hline 8 & Rarotonga & 2,700 & 1789 \\
\hline 9 & Tongatabu & 4,300 & 1789 \\
\hline 10 & Ono-i-Lau & 4,675 & 1789 \\
\hline 11 & $\begin{array}{c}\text { Hunga Ha'apai \& } \\
\text { Hunga Tonga }\end{array}$ & 5,020 & 1789 \\
\hline 12 & Pitcairn Island & 9,475 & 1790 \\
\hline 13 & $\begin{array}{c}\text { Massa Fuero } \\
\text { (Alejandro Selkirk } \\
\text { Island) }\end{array}$ & 14,305 & 1817 \\
\hline 14 & Coquimbo, Chile & 15,305 & 1817 \\
\hline 15 & The Marquesas & 22,705 & 1818 \\
\hline 16 & Tahiti & 24,090 & 1818 \\
\hline \multicolumn{3}{|c|}{} \\
\hline
\end{tabular}

\section{Jenny's Journey: 1789-1818}

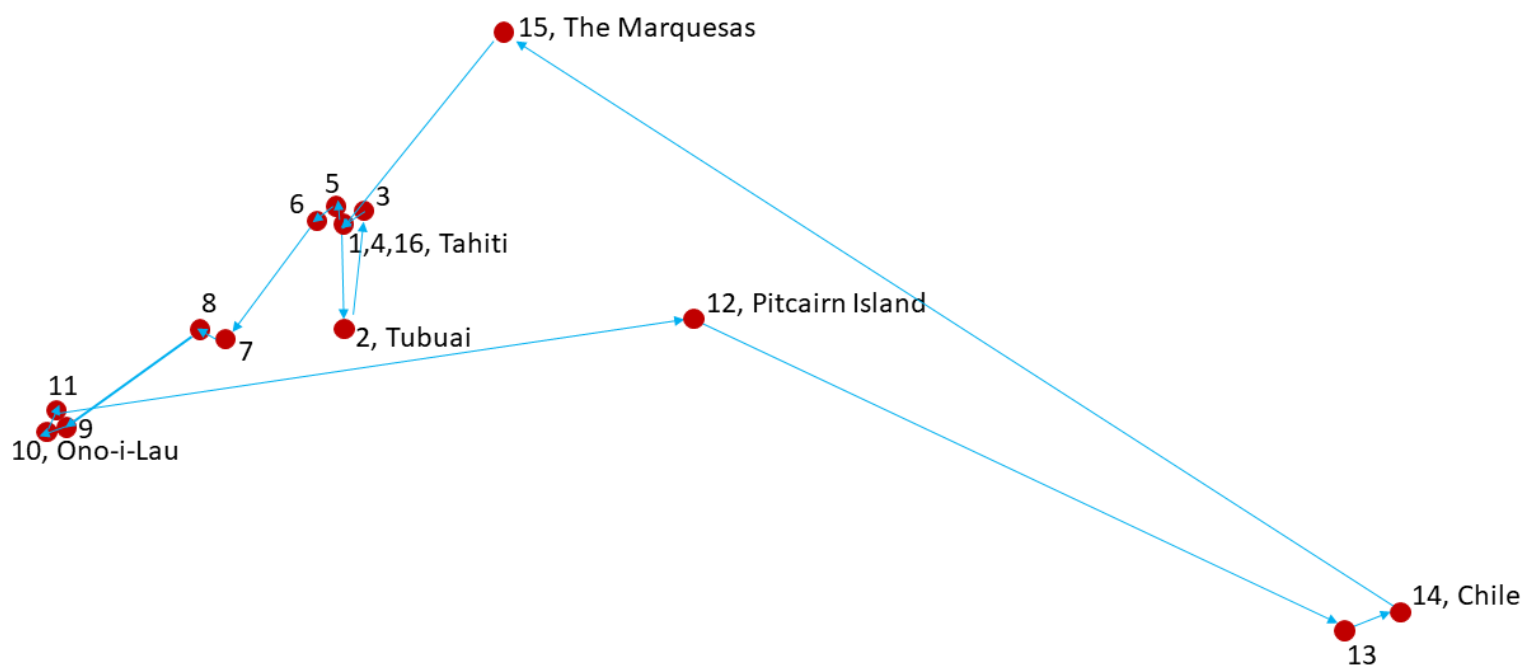

Figure 4. Jenny's journey, 1789-1818: Waypoints, link, and place names. See Table 3 for all waypoint place names. 
Jenny traveled $24,090 \mathrm{~km}$ or more than half the circumference of the Earth. That is approximately the distance to and from Sydney and Los Angeles. The journey to Pitcairn alone contributed 9,475 $\mathrm{km}$ or almost $24 \%$ of her total kilometers (Table 3). The longest link is 7,400 km from Coquimbo, Chile, to The Marquesas. Six of the links were over 1,000 km, ranging from $1,660-7,400 \mathrm{~km}$. The shortest links were the $4^{\text {th }}$ and $5^{\text {th }}$, or $55 \mathrm{~km}$ each between Matavia Bay to Tetiatora and Tetiatora to Moorea. Of the 12 Bounty women, seven never returned to Tahiti and ended their journey on Pitcairn Island. Of the four that migrated to Tahiti in 1831, two returned to Pitcairn Island, and two died on Tahiti during that same year.

\section{Discussion}

Examples of adventurers reenacting and retracing historic or legendary journeys are too numerous to recount here. Whether by foot, water, or air, daring individuals aspired to remember the great voyages, expeditions, migrations and exploits from the past. In 1947, Thor Heyerdahl sailed a traditional reed craft, the now famous Kon-Tiki, from Peru west across the South Pacific Ocean to the Tuamotu Archipelago (Heyerdahl, 2009). In the 1970s, the Polynesian Voyaging Society built a traditionally designed oceangoing vessel named Hōkūle'a (Finney, 1992). On its first expedition in 1976, the Hōkūle'a made a successful two-way expedition from Hawaii to Tahiti using ancient navigational skills (Lewis, 1972). The Bounty saga has inspired its share of commemorative voyages using replicas of the HMS Bounty and its launch. Unfortunately, the Bounty replica launched in 1960 and used for the Mutiny on the Bounty (1962), starring Marlon Brando, sank off the coast of North Carolina on 29 October 2012. There have been at least three $(1983,2010,2017)$ reenactments of the Bounty's launch openboat journey from Tonga to Timor. The most iconic of these reenactments was the 1983 voyage commanded by William Bligh-Ware, a direct descendent of Captain William Bligh of the Bounty.

While these reenactments were fantastic exploits, not everyone has the mental, physical, and financial resources to undertake such daring adventures. Google Earth and other technologies such as webcams and drones offer arm-chair adventurers, history enthusiasts, and scholars a glimpse of what the actual participants saw, in our case Jenny. Following a protagonist from place to place across space and time affords an inkling of what it might have been like had you been there. Footstep biographies in vogue (e.g., Randell Jones' In the Footsteps of Daniel Boone) are a testament to the success of this strategy of capturing relevant locations in the life of a historic figure (Jones, 2005). Google Earth enhances our opportunities to understand locations associated with the geographical past by allowing the user to manipulate orientation, scale, perspective (2D or $3 \mathrm{D})$, and enhance with text and images, including turning on or off photographs included within the browser. There is also the functionality to display multiple paths, so future projects could add the pre-mutiny track of the Bounty, Bligh's open boat journey from Tofua to Timor, the HMS Pandora's search for the Bounty, and Bligh's second breadfruit expedition on the HMS Providence and Assistant.

\section{Conclusion}

With the exception of Jenny, the historical archives include surprisingly little information attributed directly to the women of the Bounty. This does not mean their role in shaping life 
on Pitcairn has not been substantial or recognized. A 1956 movie titled The Women of Pitcairn appeared on the big screen. As might be expected from a Hollywood rendition, the storyline highlights a fictionalized plot that romanticizes and sexualizes the women of Pitcairn Island. The movie begins after all the male Bounty mutineers have died, leaving an island of women to be lusted after by a gang of shipwrecked sailors. This storyline perpetuates western man's image of the idealized Polynesian woman that is fostered by the myth of 'le bon sauvage'. Glynn Christian, a descendent of Fletcher Christian, offers a more complex view of the women of Pitcairn in a historical fiction titled Mrs. Christian, mutineer Fletcher stole the ship: She mutinied and gave women the right to vote. Despite having a rather convoluted title, this book portrays the important role of female agency in shaping their lives on the island (Christian, 2011).

These 12 women, including Jenny, and one girl, appear in a joint Pitcairn Islands and French Polynesia stamp issue titled, 'Women of the Bounty'. The stamps commemorate the active role these women had in shaping their social landscape (Parker, 2016). These stamps, designed by Lucas Kukler of Bangkok, Thailand, were available for sale from the respective postal authorities for a period of two years, beginning 30 March 2017 (Figure 5). The stamps illustrate the women's contributions to the island's economy with their participation in growing crops, fishing, and especially making tapa bark cloth. From these first settlers, subsequent generations of women have been agents of change on Pitcairn Island, as well as Norfolk Island, where many descendants reside (Norfolk Island Branch, 2011).

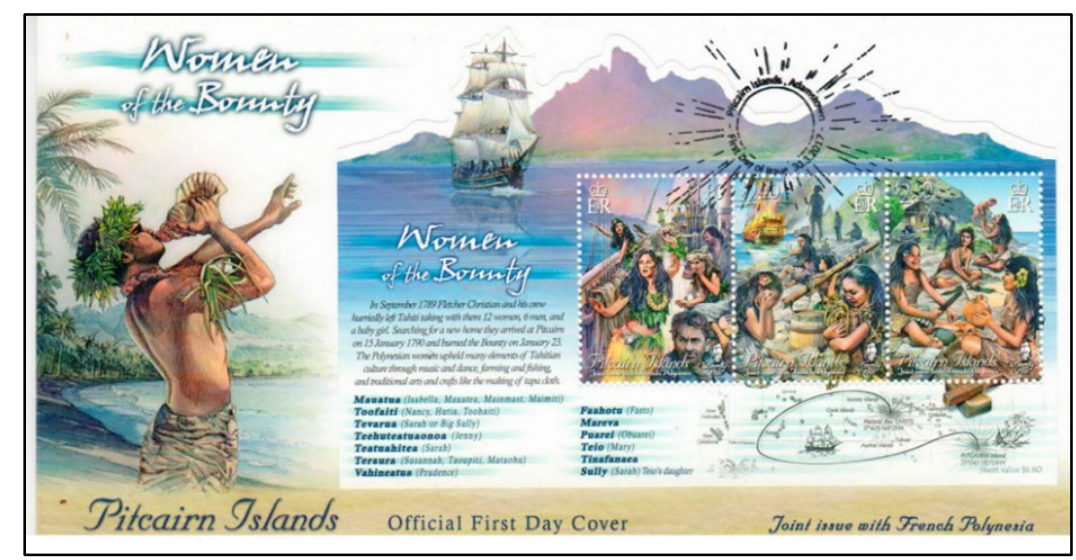

Figure 5. Women of the Bounty commemorated on an Official First Day Cover issued jointly by the Pitcairn Islands and French Polynesia (Bounty Post, 2020 from author's stamp collection).

Teehuteatuaonoa was one of 12 Polynesian women reaching Pitcairn Island with the Bounty mutineers in 1790. She is the most traveled of these women and the first to return to Tahiti after 29 years away. Her journey is recorded in Google Earth with screenshots and a caption given for each waypoint. The journey encompassed 15 links for a total of approximately $24,090 \mathrm{~km}$ or $60 \%$ of the Earth's circumference. Her longest link was 7,400 $\mathrm{km}$ on the Sultan from Coquimbo, Chile, to The Marquesas. Jenny's life provides an excellent example of female agency during this male-dominated era (late 1700s - early 1800s) when the voices of women were institutionally and socially suppressed. 


\section{Acknowledgements}

This research received financial support from the Jim and Nancy Tiller Faculty Research Endowment. This study benefited from two site visits to the Pitcairn Islands Study Center (PISC) at Pacific Union College in Angwin, California. PISC director Herbert Ford has been an invaluable resource in exploring the Pitcairn/Bounty saga. Thanks to Ave Fujimoto-Strait and Erin Owens for offering editorial comments.

\section{References}

Albert, D. (2020). The Bounty's primogeniture and the Thursday-Friday conundrum. Athens Journal of Humanities \& Arts, 7(2), 105-120. https://doi.org/10.30958/ajha.7-2-1

Albert, D. P. (2018). Did or could seabirds "Halo" Pitcairn Island for Fletcher Christian? Terrae Incognitae, 50(2): 99-114. https://doi.org/10.1080/00822884.2018.1498638

Alexander, C. (2003). The Bounty: The true story of the mutiny on the Bounty. Viking. Ball, I. M. (1973). Pitcairn: Children of mutiny. Boston. Houghton Mifflin Company.

Ball, I. (31 October 2004). We sensed a dark side to this teetotal, God-fearing little society, The Telegraph.

https://www.telegraph.co.uk/news/worldnews/australiaandthepacific/pitcairnislands/ 1475509/We-sensed-a-dark-side-to-this-teetotal-God-fearing-little-society.html

Beechey, F. W. (1931). Narrative of A voyage to the Pacific and Beering's Strait, to co-operate with the polar expeditions: Performed in his majesty's ship Blossom, under the command of Captain F. W. Beechey, R. N. In The Years 1825, 26, 27, 28. Henry Colburn and Richard Bentley.

Bligh, W., \& Christian, E. (2001). The Bounty mutiny. Penguin Books.

Bounty Post, (2020). The women of the Bounty. http://www.stamps.gov.pn/WomenOfTheBounty.html

Bodzin, A. M., \& Cirucci, L. (2009). Integrating geospatial technologies to examine urban land use change: A design partnership. Journal of Geography, 108(4/5), 186-197. https://doi.org/10.1080/00221340903344920

Christian, G. (2011). Mrs Christian: 'Bounty' mutineer. [Place of publication not identified]: The Long Riders' Guild Press.

Connell, J. (2003). Island dreaming: The contemplation of Polynesia paradise. Journal of Historical Geography, 29(4): 554-581. https://doi.org/10.1006/jhge.2002.0461

Dening, G. (1992). Mr. Bligh's bad language: Passion, power, and theatre on the Bounty. Cambridge University Press.

Dillon, P. (1829). Narrative and successful result of a voyage in the South Seas performed by order of the government of British India, to ascertain the actual fate of La Pérouse's expedition interspersed with accounts of the religion, manners, customs and cannibal practices of the South Sea islanders. Hurst, Chance and Co.

Finney, B. (1992). From sea to space. Massey University.

Fitzsimons, P. (2018). Mutiny on the Bounty. Hachette Australia.

Ford, H. (1996). Pitcairn: Port of call. Hawser Titles.

Google (n.d.). Google Earth. https://www.google.com/earth/

Heyerdahl, T. (2009). Kon-Tik: Across the Pacific by raft. Simon and Schuster 
Hsu, H.-P., Tsai, B.-W., \& Chen, C.-M. (2018). Teaching topographic map skills and geomorphology concepts with Google Earth in a one-computer classroom. Journal of Geography, 117(1), 29-39. https://doi.org/10.1080/00221341.2017.1346138

Jones, K. R. (2005). In the footsteps of Daniel Boone. John F. Blair.

Kirk, R. W. (2008). Pitcairn Island, the Bounty mutineers, and their descendants: A history. McFarland \& Co.

Kotzebue, Otto von. (1830). A new voyage round the world, in the years 1823, 24, 25, and 26. 2 vols. Colburn and Bentley.

Krakowka, A. (2012). Field trips as valuable learning experiences in geography courses. Journal of Geography, 111(6), 236-244. https://doi.org/10.1080/00221341.2012.707674

Kulo, V., \& Bodzin, A. (2011). Integrating geospatial technologies in an energy unit. Journal of Geography, 110(6), 239-251. https://doi.org/10.1080/00221341.2011.566344

Langdon, R. (2000). 'Dusky Damsels': Pitcairn Island's neglected matriarchs of the Bounty Saga. The Journal of Pacific History, 35(1), 29-47. https://doi.org/10.1080/713682826

Lareau, P. J. (1999). The H.M.S. Bounty genealogies, 4th Edition, St. Paul: Minnesota.

Lewis, D. (1972). We, the navigators: The ancient art of landfinding in the Pacific. University Press of Hawaii.

Maude, H. E. (1968). Of islands \& men: Studies in Pacific history. Oxford University Press.

Maude, H. E. (1958). In search of a home: From the mutiny to Pitcairn Island (1789-1790). The Journal of the Polynesian Society, 67(2), 104-131.

Murray, S. (1992). Pitcairn Island, the first 200 years. Bounty Sagas.

Nechtman, T. W. (2018). The pretender of Pitcairn Island: Joshua W. Hill - the man who would be king among the Bounty mutineers. Cambridge University Press.

Nicolson, R. B., \& Davies B. F. (1997). The Pitcairners. University of Hawaii Press.

Norfolk Island Branch of the CPA. (2011). Women as Agents of Change. Commonwealth Parliamentary Association.

Parker, E. L. (2016). The women of the Bounty. Australian Folklore, 31, 171-172.

Patterson, T. C. (2007). Google Earth as a (not just) geography education tool. Journal of Geography, 106(4), 145-152. https://doi.org/10.1080/00221340701678032

Raine, T. (1824). Narrative of a visit to Pitcairn's Island in the year 1821, The Literary Chronicle and Weekly Review, 270, July 17, pp. 460-462.

Reason, J. (1938). The bricklayer and the King: Henry Nott of the South Seas. Edinburgh House.

Reynolds, P. (2016). Tapa cloths and beaters: Tradition, innovation and the agency of the Bounty women in shaping a new culture on Pitcairn Island from 1790 to 1850. Textile History, 47(2,) 190-207. https://doi.org/10.1080/00404969.2016.1211435

Reynolds, P. (2011a). Our Polynesian foremothers. Women as Agents of Change. Commonwealth Parliamentary Association and the Norfolk Island Branch of the CPA. Reynolds, P. (2011b). The forgotten women of the Bounty and their material heritage. Whatu Raranga a Kiwa, Understanding and Uniting Mori and Pacific Textiles. Maori \& Pacific Textile Symposium, 10th - 11th June. Wellington, New Zealand. https://hdl.handle.net/1959.11/20140

Salmond, A. (2011). Bligh: William Bligh in the South Seas. University of California Press.

Salmond, A. (2010). Aphrodite's island: The European discovery of Tahiti. University of California Press. 
Schultz, R. B., Kerski, J. J., \& Patterson, T. C. (2008). The use of virtual globes as a spatial teaching tool with suggestions for metadata standards. Journal of Geography, 107(1), 2734.https://doi.org/10.1080/00221340802049844

Scott, B. W. (1982). The true identity of John Adams. The Mariner's Mirror, 68(1), 31-39. https://doi.org/10.1080/00253359.1982.10655844

Silverman, D. (1967). Pitcairn Island. The World Publishing Company.

Tamaira, A. (2010). From full dusk to full tusk: Reimagining the 'dusky maiden' through the visual arts. The Contemporary Pacific, 22(1), 1-35.

Thomas, N. (2010). Islanders: The Pacific in the age of empire. Yale University Press.

Topliff, S., Jr. (1821). Pitcairn Island. Salem Gazette, January 16, 2.

Teehuteatuaonoa (or Jenny). (2 October 1826). Bengal Hurkaru, reprinted as "Pitcairn's Island, the Bounty's Crew," United Service Journal and Naval and Military Magazine, 1829, pt. II: 589-593.

Teehuteatuaonoa (or Jenny). (17 July 1819). Account of the mutineers of the ship Bounty, and their descendants at Pitcairn's Island. Sydney Gazette and New South Wales Advertiser.

Wahlroos, S. (1989). Mutiny and romance in the South Seas: A companion to the Bounty adventure. Salem House.

Zhu, L., Pan, X., \& Gao, G. (2016). Assessing place location knowledge using a virtual globe. Journal of Geography, 115(2), 72-80. https://doi.org/10.1080/00221341.2015.1043930 